\title{
Synthesis and Properties of $\mathrm{ZnO} / \mathrm{Al}$ Thin Films Prepared by Dip-Coating Process
}

\author{
Inna Juhnevica ${ }^{1}$, Marija Masonkina ${ }^{2}$, Gundars Mezinskis ${ }^{3}$, Aḷona Gabrene ${ }^{4}$, \\ ${ }^{1-4}$ Riga Technical University
}

\begin{abstract}
In this work sol-gel dip-coating technique was used to synthesize $\mathrm{ZnO}$ and $\mathrm{ZnO} / \mathrm{Al}$ films. The influence of annealing regime and dopant concentration on the structural properties of $\mathrm{ZnO}$ and aluminum doped $\mathrm{ZnO}$ ( $\mathrm{ZnO} / \mathrm{Al})$ films was investigated. The surface morphology and crystallinity of $\mathrm{ZnO}$ films were determined using atomic force microscopy and $\mathrm{X}$-ray diffraction, respectively. The experimental results show that $\mathrm{ZnO}$ and $\mathrm{ZnO} / \mathrm{Al}$ films prepared using "shock" conditions have smooth surfaces and uniform grains. Increase of aluminum concentration led to grain size reduction and denser film.
\end{abstract}

Keywords - $\mathrm{ZnO} / \mathrm{Al}$, thin film, dip-coating, annealing conditions.

\section{INTRODUCTION}

Zinc oxide is a transparent semiconducting oxide with a direct wide band gap $(3.37 \mathrm{eV})$ [1]. $\mathrm{ZnO}$ nanoparticles have piezoelectric, electric and optical properties and they also show ultraviolet emission near band gap. Possible applications of $\mathrm{ZnO}$ nanoparticles are humidity and gas sensors, photoelements and light emitting diodes [2], varistors [3], surface acoustic wave devices [4], optical waveguides [5], solar cells [6], etc.

High electrical conductivity, optical transparency in wide range and resistance to hydrogen plasma exposure of $\mathrm{ZnO}$ films doped with III group elements (B, Ga, In) makes them prospective materials for application in transparent electrodes, optoelectronic devices and solar cells [7], [8].

Doped zinc oxide $(\mathrm{ZnO})$ thin films (including with $\mathrm{Al}^{3+}$ ) are a promising alternative for indium tin oxide transparent conducting films, due to high conductivity and excellent optical properties. $\mathrm{ZnO} / \mathrm{Al}$ thin films can be produced by many methods such as chemical vapour deposition [9], radio frequency sputtering [10], sol-gel dip-coating [11], spray pyrolysis [12].

In this work we have studied the structural and optical properties of $\mathrm{ZnO} / \mathrm{Al}$ thin films prepared by sol-gel dip-coating process.

\section{EXPERIMENTAL SECTION}

\section{A. Materials}

Zinc acetate dihydrate $\left(\mathrm{Zn}\left(\mathrm{CH}_{3} \mathrm{COO}\right)_{2} \cdot 2 \mathrm{H}_{2} \mathrm{O}\right)$, diethanolamine (DEA), aluminium nitrate nonahydrate $\left(\mathrm{Al}\left(\mathrm{NO}_{3}\right)_{3} \cdot 9 \mathrm{H}_{2} \mathrm{O}\right)$ were obtained from Sigma Aldrich. All the reagents used in the experiments were analytical grade and were used without further purification. During experiments samples with different mole fraction of $\mathrm{Al}^{3+}$ were prepared $0 \%$, $1 \%$ and $5 \%$.

\section{B. Characterization}

The effect of the annealing conditions on the particle size of the synthesized $\mathrm{ZnO}$ nanoparticles was studied using powder X-ray diffraction (XRD) with X-ray diffractometer Rigaku Ultima+. $\mathrm{Cu} \mathrm{K} \alpha$ radiation was used in XRD. Scanning electron microscopy (SEM) images were obtained using scanning electron microscope T200 - JEOL at an accelerating voltage $5 \mathrm{kV}$. Atomic force microscopy (AFM) was done using Veeco SPM II microscope in a non-contact mode. AFM measurements were used to investigate the effect of $\mathrm{Al}^{3+}$ doping on the microstructure of $\mathrm{ZnO} / \mathrm{Al}$ films. $\mathrm{Al}^{3+}$ doping influence on optical properties of the films was studied using Speccord 210 PC ultraviolet-visible light (UV-VIS) spectrometer.

\section{Preparation of ZnO/Al Thin Films}

A precursor solution was synthesized by dissolving zinc acetate dihydrate in ethanol and DEA solution. The concentration of zinc ions was $0.5 \mathrm{M}$, and the molar ratio of DEA to zinc ions was maintained at 1.0. The volume ratio of $\mathrm{C}_{2} \mathrm{H}_{5} \mathrm{OH}: \mathrm{DEA}: \mathrm{Zn}\left(\mathrm{CH}_{3} \mathrm{COO}\right)_{2} \cdot 2 \mathrm{H}_{2} \mathrm{O}$ was $89: 5: 6$. The solution was stirred at $60^{\circ} \mathrm{C}$ for $2 \mathrm{~h}$ to yield a clear and transparent sol. $\mathrm{Al}\left(\mathrm{NO}_{3}\right)_{3} \cdot 9 \mathrm{H}_{2} \mathrm{O}$ was used as a dopant with mole fraction $0 \%, 1 \%$ and $5 \%$ to form $\mathrm{ZnO}, \mathrm{ZnO} / \mathrm{Al}-1$ and $\mathrm{ZnO} / \mathrm{Al}-5$ samples, respectively. After addition of $\mathrm{Al}\left(\mathrm{NO}_{3}\right)_{3} \cdot 9 \mathrm{H}_{2} \mathrm{O}$, solution was stirred for further $1.5 \mathrm{~h}$. The solution was then aged in room temperature for $24 \mathrm{~h}$. The precursor solution was deposited on Menzel-Gläser sodium silicate glass substrates by dip-coating process. Glass substrates were cleaned using $\mathrm{CeO}_{2}$, soap, distilled water and ethanol. After coating the substrates were pre-heated at $200{ }^{\circ} \mathrm{C}$ for $10 \mathrm{~min}$. Then the films were transformed into nanocrystalline pure or aluminium-doped $\mathrm{ZnO}$ films by thermal treatment at $500{ }^{\circ} \mathrm{C}$ for $30 \mathrm{~min}$. Two different thermal treatment methods were used: gradual increase of the temperature, with increase rate $5^{\circ} \mathrm{C} / \mathrm{min}$, or using "shock" conditions (specimens were inserted in the maximal temperature $500{ }^{\circ} \mathrm{C}$ ).

\section{RESULTS AND DISCUSSION}

\section{A. Results}

The surface morphologies of the $\mathrm{ZnO}, \mathrm{ZnO} / \mathrm{Al}-1$ and $\mathrm{ZnO} / \mathrm{Al}-5$ films measured by AFM are presented in Fig. 1. Two different annealing treatments of $\mathrm{ZnO}$ and $\mathrm{ZnO} / \mathrm{Al}$ films are the gradual increase of the temperature and the "shock" conditions. Fig. 2 shows the surface roughness of the films and Fig. 3 shows 
the average grain size of the films. For samples annealed using gradual increase of temperature the surface was relatively rough, they had bigger grain size and inhomogeneous grain distribution along the specimens compared to samples annealed using "shock" conditions. Upon comparison of samples with different amounts of $\mathrm{Al}^{3+}$, it can be seen that temperature treatment method has a significant influence on $\mathrm{ZnO} / \mathrm{Al}$ surface.

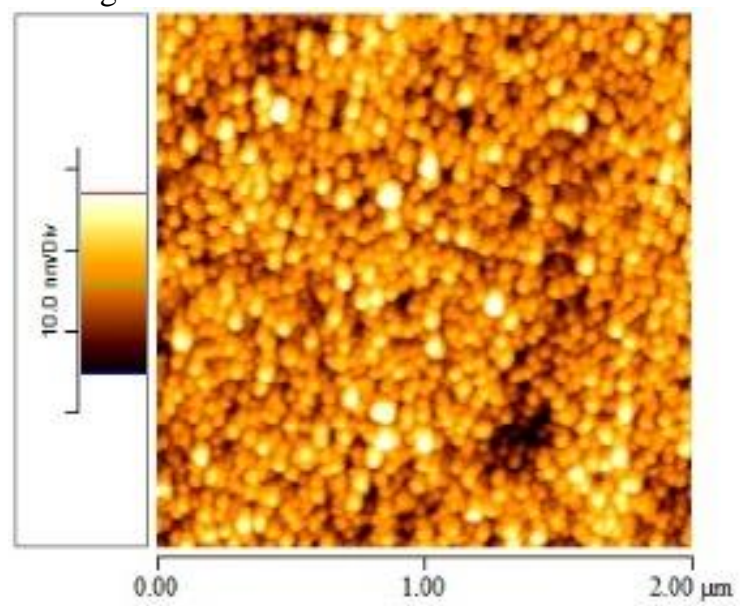

a

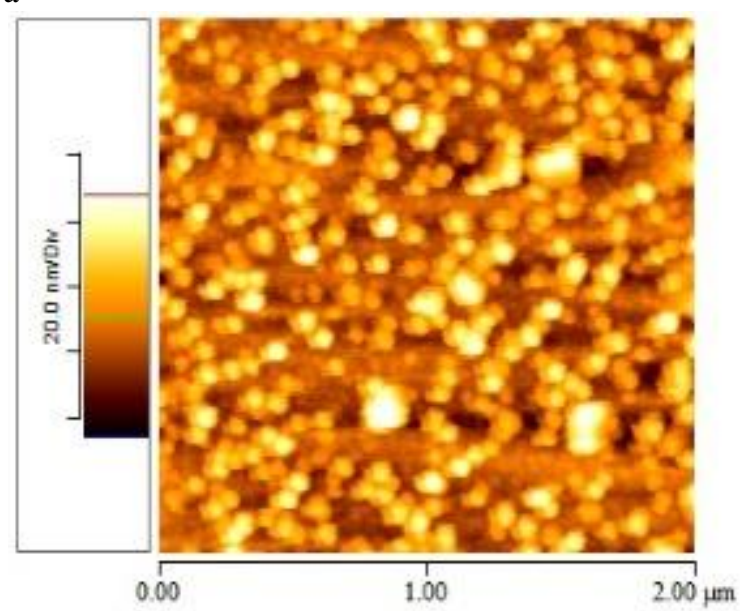

c

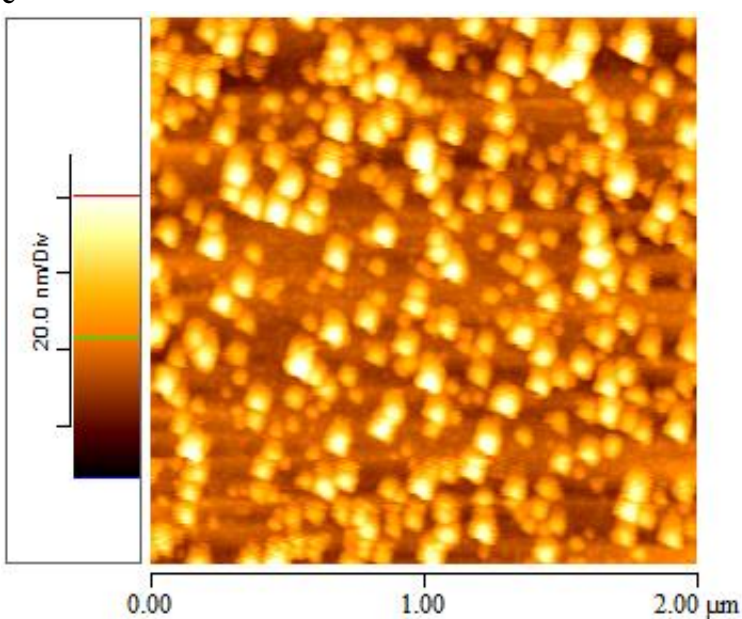

e

Fig. 1. AFM results showing $\mathrm{ZnO}$ (a and b), $\mathrm{ZnO} / \mathrm{Al}-1$ ( $\mathrm{c}$ and $\mathrm{d}$ ) and $\mathrm{ZnO} / \mathrm{Al}-5$ (e and f) film morphology. The films are annealed using different conditions: a), c) and e) gradually increasing temperature by $5{ }^{\circ} \mathrm{C} / \mathrm{min}$; b), d) and f) "shock" conditions.

For samples obtained using "shock" conditions, $\mathrm{ZnO}$ doping with $\mathrm{Al}^{3+}$ led to finer grain sizes. For samples obtained using gradual temperature increase $\mathrm{Al}^{3+}$ doping led to an opposite effect.

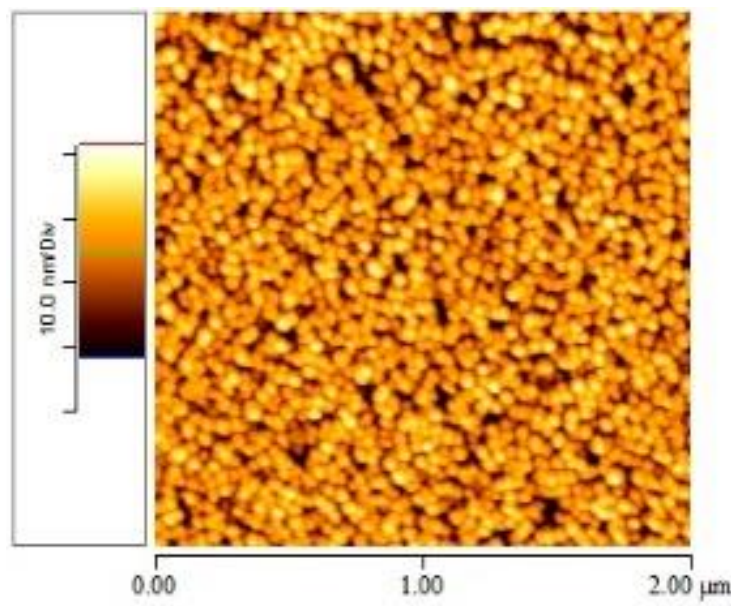

b

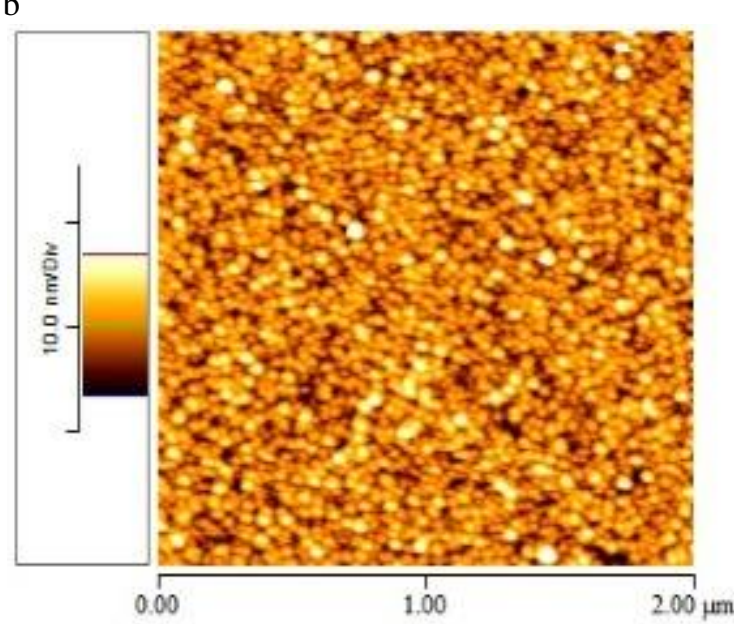

d

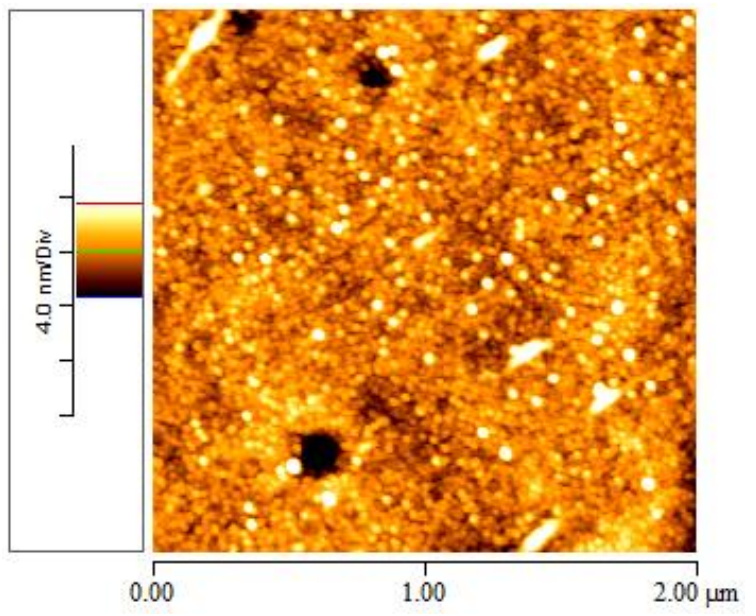

f 
The crystal structures in thin films were identified using XRD. Fig. 4 displays the X-ray diffraction patterns of the samples annealed using "shock" conditions. For both $\mathrm{ZnO}$ and $\mathrm{ZnO} / \mathrm{Al}$ films the patterns corresponded to five diffraction peaks of crystalline $\mathrm{ZnO}$ : (100), (002), (101), (102), (110). This indicates that films had a hexagonal wurtzite structure.

Fig. 5 shows optical transmittance spectra of samples $\mathrm{ZnO}$, $\mathrm{ZnO} / \mathrm{Al}-1$ and $\mathrm{ZnO} / \mathrm{Al}-5$ in range from $300 \mathrm{~nm}$ to $740 \mathrm{~nm}$. Upon doping $\mathrm{ZnO}$ with $\mathrm{Al}^{3+}$ the optical transmittance increased in direct proportion to the changes of $\mathrm{Al}^{3+}$ concentration.

Optical transmittance of $\mathrm{ZnO}$ sample was $82.28 \%$. For $\mathrm{ZnO} / \mathrm{Al}-1$ sample optical transmittance was $88.45 \%$ and for $\mathrm{ZnO} / \mathrm{Al}-5$ sample optical transmittance was $91.03 \%$.

For investigation of concentration of $\mathrm{Al}^{3+}$ influence on film morphology SEM was performed. SEM results are presented in Fig. 6. In SEM images it can be seen that the coatings consisted of individual grains that are densely arranged. Furthermore, with the increase of $\mathrm{Al}^{3+}$ dopant concentration, grains were arranged more densely. Pure $\mathrm{ZnO}$ film had larger grain size, but narrower grain size distribution, compared to $\mathrm{ZnO} / \mathrm{Al}$ films. For $\mathrm{ZnO} / \mathrm{Al}$ films grain size decreased, if $\mathrm{Al}^{3+}$ concentration increased.

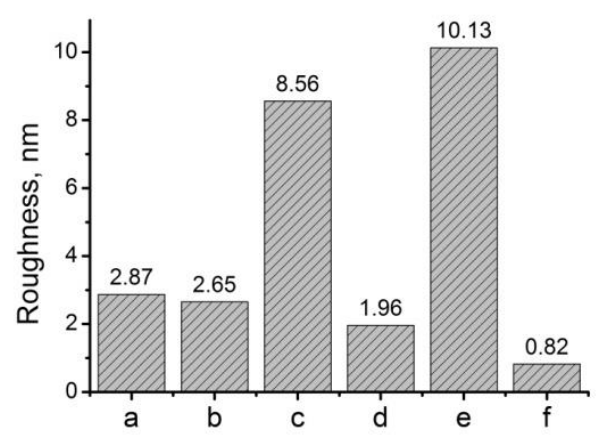

Fig. 2. $\mathrm{ZnO}$ (a and b), $\mathrm{ZnO} / \mathrm{Al}-1$ (c and d) and $\mathrm{ZnO} / \mathrm{Al}-5$ (e and f) film roughness annealed at different conditions: a), c) and e) gradually increasing temperature with increase rate $5^{\circ} \mathrm{C} / \mathrm{min} ; \mathrm{b}$ ), d) and f) "shock" conditions.

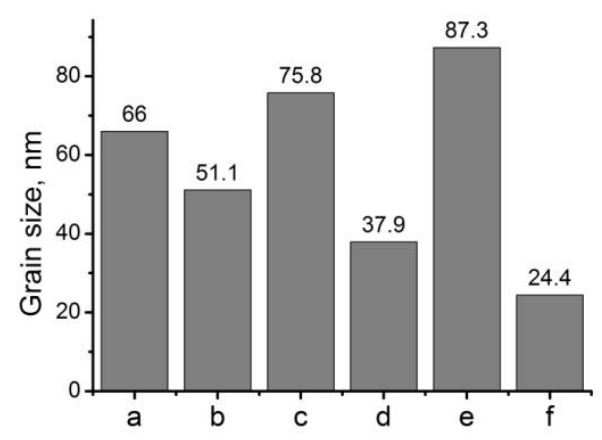

Fig. 3. Grain sizes of $\mathrm{ZnO}$ (a and b), $\mathrm{ZnO} / \mathrm{Al}-1$ (c and d) and $\mathrm{ZnO} / \mathrm{Al}-5$ (e and f) films annealed at different conditions: a), c) and e) gradually increasing temperature with increase rate $5^{\circ} \mathrm{C} / \mathrm{min} ; \mathrm{b}$ ), d) and f) "shock" conditions.

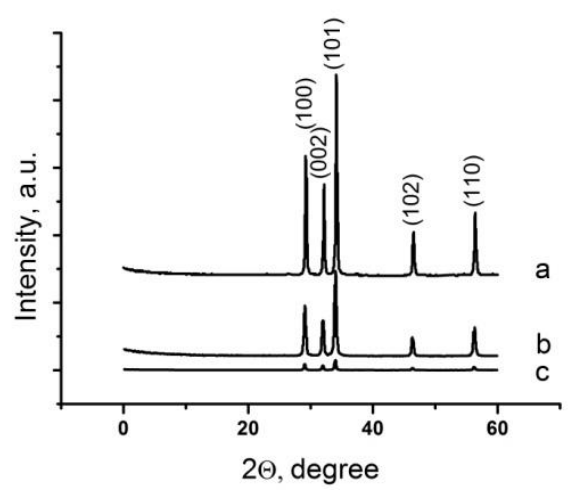

Fig. 4. $\mathrm{X}$-ray diffraction pattern of $\mathrm{ZnO}$ (a), $\mathrm{ZnO} / \mathrm{Al}-1$ films (b) and $\mathrm{ZnO} / \mathrm{Al}-$ 5 (c).

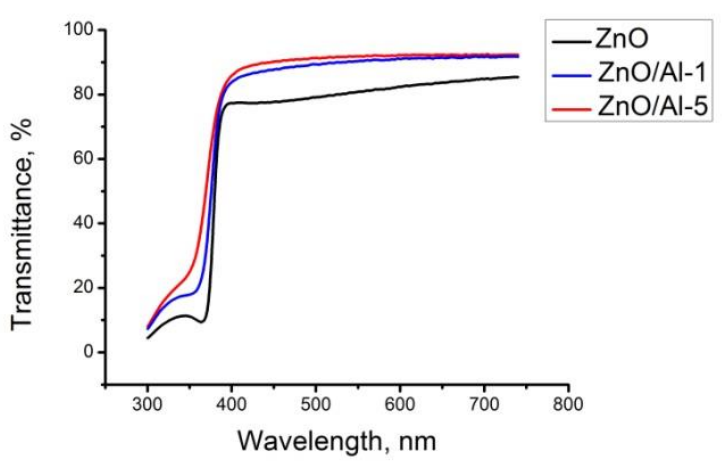

Fig. 5. Optical transmittance spectra of $\mathrm{ZnO}$ and $\mathrm{ZnO} / \mathrm{Al}$ obtained using "shock" conditions.

\section{B. Discussion}

The possible reason for higher roughness of samples annealed with gradual increase of temperature (see Fig. 1) is given in the further text. Samples annealed with gradual increase of temperature formed irregular particle size distribution, because the growth of the particles occurs gradually starting from the upper layers and spread in depth, so the particle growth on the surface limited the growth of the particles located in inner layers. Conversely, in coatings, obtained using "shock" conditions, the particle growth occurred uniformly at all film depths. Gradual increase of the annealing temperature also caused crystalline lattice deformation due to anisotropic thermal motion, but when using the "shock" conditions crystal lattice deformation did not have time to take place, when the sample reached the maximum temperature momentarily.

In Fig. 4 XRD results for pure and $\mathrm{Al}^{3+}$ doped $\mathrm{ZnO}$ films are shown. In both cases there was $\mathrm{ZnO}$ wurtzite crystalline phase. The intensities of diffraction peaks of the (100), (002), (101), (102) and (110) planes tended to decrease with entry of $\mathrm{Al}^{3+}$ dopant. This indicates that doping with $\mathrm{Al}^{3+}$ decreased the crystallinity of $\mathrm{ZnO}$ films. In XRD patterns of both $\mathrm{ZnO} / \mathrm{Al}-1$ and $\mathrm{ZnO} / \mathrm{Al}-5$ no new peaks appeared. This could be caused by interaction between $\mathrm{Al}^{3+}$ and $\mathrm{ZnO}$. It may be due to the fact that $\mathrm{Al}^{3+}$ upon entering the $\mathrm{ZnO}$ structure did not form a 
crystalline phase or solid solutions with $\mathrm{ZnO}$ system or that the concentration of $\mathrm{Al}^{3+}$ is too low.

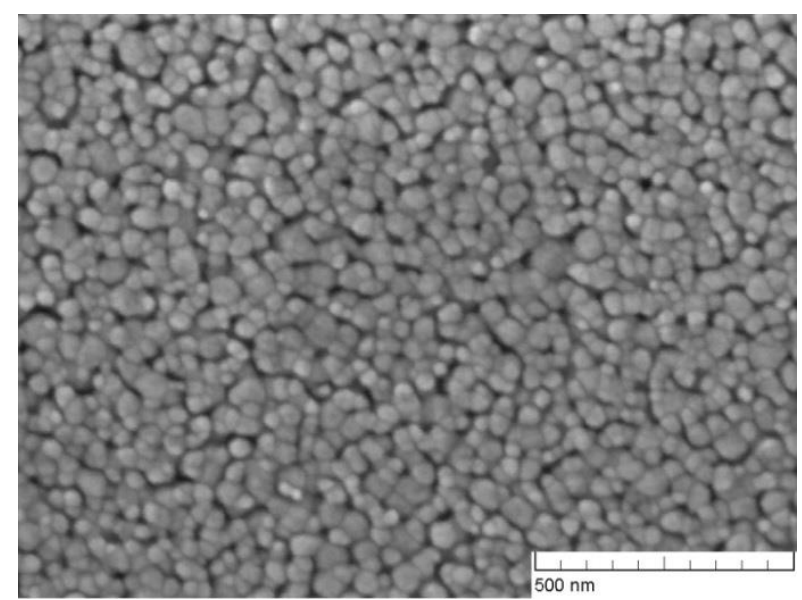

a

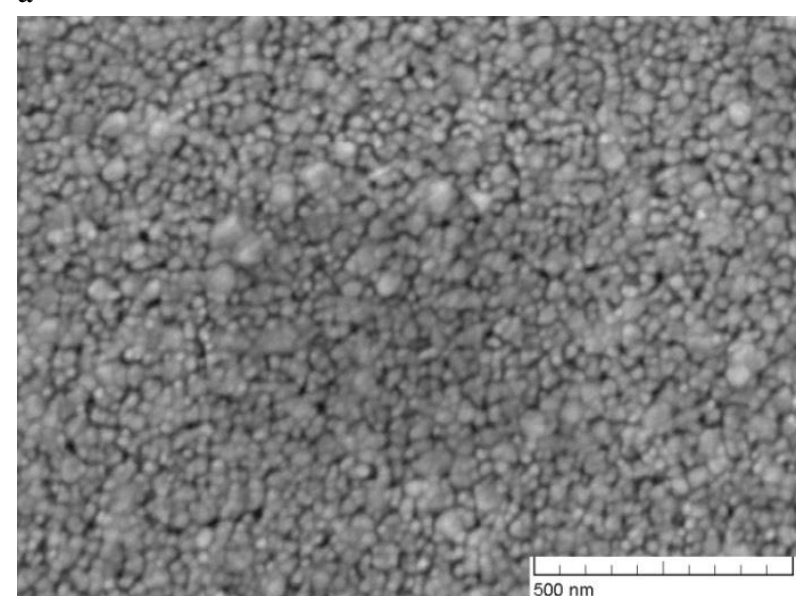

b

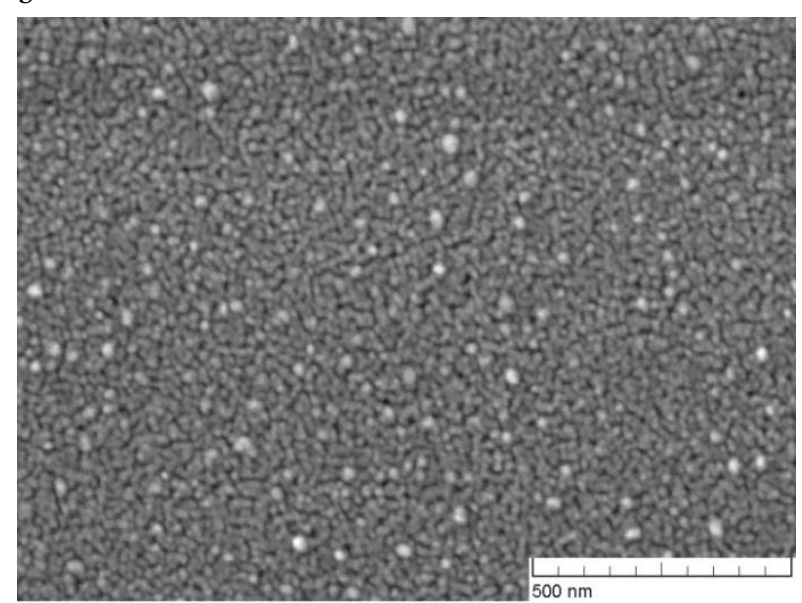

c

Fig. 6. SEM microscope images of $\mathrm{ZnO}$ and $\mathrm{ZnO} / \mathrm{Al}$ filmsobtained using "shock" conditions: a) pure $\mathrm{ZnO}$ film; b) $1 \%$ mole fraction $\mathrm{Al}^{3+}$ doped film $(\mathrm{ZnO} / \mathrm{Al}-1)$; c) $5 \%$ mole fraction $\mathrm{Al}^{3+}$ doped film ( $\mathrm{ZnO} / \mathrm{Al}-5)$.

Optical transmittance spectra of samples shown in Fig. 5. It shows that doping of $\mathrm{ZnO}$ with $\mathrm{Al}^{3+}$ increase the intensity of optical transmittance; this can be explained by decrease of porosity in $\mathrm{ZnO} / \mathrm{Al}$ samples. Reduction of porosity is explained by the particle size distribution - smaller particles filled in the gaps between larger particles, thus preventing the formation of pores.

SEM images in Fig. 6 show that between the particles pores were formed. This can be determined by both optical and electrical properties of the material. Since the samples doped with $\mathrm{Al}^{3+}$ had smaller particle sizes than the $\mathrm{ZnO}$ model, the amount of pores in these samples decreased due to the formation of particles in denser arrangement.

\section{CONCLUSION}

$\mathrm{ZnO}$ and $\mathrm{ZnO} / \mathrm{Al}$ thin films were coated on sodium-silicate glass substrate by sol-gel dip-coating method. Influence of annealing conditions on the morphology of thin films was investigated. Surface of the specimens annealed in "shock" conditions had better quality, lower roughness and smaller particle size.

Studies on the effects of the $\mathrm{Al}^{3+}$ concentration on $\mathrm{ZnO} / \mathrm{Al}$ thin film morphology indicated that the increase of $\mathrm{Al}^{3+}$ concentration in $\mathrm{ZnO}$ composition led to decrease of particle size in the films and formation of denser particle arrangement; this resulted in an increase of optical transmittance.

\section{ACKOWLEDGEMENT}

This work has received a financial support of the ERDF "Development of solar heat absorbing materials by means of sol-gel and vacuum technologies" (Project No 2DP/2.1.1.1.0/10/APIA/VIAA/156).

\section{REFERENCES}

1. Rajesh S., Ganesh T., Xavier F.P. Thickness dependent microstructure, optical and photo conducting properties of $\mathrm{ZnO}$ thin films prepared by spin coating process. Journal of Electron Devices, 2013, vol. 17, pp. 1417-1422.

2. Shrestha S.P., Ghimire R., Nakarmi J.J., Kim Y.S., Shrestha S., Park C.Y., Boo J.H. Properties of ZnO:Al films prepared by spin coating of aged precursor solution. B Korean Chem. Soc., 2010, vol. 31, pp. 112-115. http://dx.doi.org/10.5012/bkcs.2010.31.01.112

3. Wang Q., Qin Y., Xu G.J., Chen L., Li Y., Duan L., Li Z.X., Li Y.L., Cui P. Low-voltage $\mathrm{ZnO}$ varistor fabricated by the solution-coating method. Ceramics International, 2008, vol. 34, pp. 1697-1701. http://dx.doi.org/10.1016/j.ceramint.2007.05.012

4. Krishnamoorthy S., Iliadis A.A. Properties of High Sensitivity ZnO Surface Acoustic Wave Sensors on $\mathrm{SiO}_{2} /(100)$ Si Substrates. Solid-State Electronics, 2008, vol. 52, pp. 17101716. http://dx.doi.org/10.1016/j.sse.2008.06.039

5. Jia C.L., Wang K.M., Wang X.L., Zhang X.J., Lu F. Formation of caxis oriented $\mathrm{ZnO}$ optical waveguides by radio-frequency magnetron sputtering. Optics Express, 2005, vol. 13, pp. 5093-5099. http://dx.doi.org/10.1364/OPEX.13.005093

6. Wienke J., van der Zanden B., Tijssen M., Zeman M. Performance of spray-deposited $\mathrm{ZnO}$ :In layers as front electrodes in thin-film silicon solar cells. Solar Energy Materials and Solar Cells, 2008, vol. 92, pp. 884-890. http://dx.doi.org/10.1016/j.solmat.2008.01.023 
7. Guo J., Zheng J., Song X., Sun K. Synthesis and conductive properties of $\mathrm{Ga}$-doped $\mathrm{ZnO}$ nanosheets by the hydrothermal method. Mater. Lett., 2013, vol. 97, pp. 34-36. http://dx.doi.org/10.1016/j.matlet.2013.01.055

8. Wu F., Fang L., Pan Y.J., Zhou K., Ruan H.B., Liu G.B., Kong C.Y. Effect of annealing treatment on structural, electrical, and optical properties of Ga-doped $\mathrm{ZnO}$ thin films deposited by RF magnetron sputtering. Thin Solid Films, 2011, vol. 520, pp. 703-707. http://dx.doi.org/10.1016/j.tsf.2011.04.147

9. Wu Z.Y., Cai J.H., Ni G. ZnO films fabricated by chemical bath deposition from zinc nitrate and ammonium citrate tribasic solution. Thin Solid Films, 2008, vol. 516, pp. 7318-7322. http://dx.doi.org/10.1016/j.tsf.2008.01.014

10. Zhang D.H., Yang T.L., Wang Q.P., Zhang D.J. Electrical and optical properties of Al-doped transparent conducting $\mathrm{ZnO}$ films deposited on organic substrate by RF sputtering. Mater. Chem. Phys., 2001, vol. 68, pp. 233-238. http://dx.doi.org/10.1016/S0254-0584(00)00359-X

11. Zi-Neng N., Kah-Yoong C., Thanaporn T. Effects of annealing temperature on $\mathrm{ZnO}$ and $\mathrm{AZO}$ films prepared by solgel technique. Appl. Surf. Sci., 2012, vol. 258, pp. 9604-9609. http://dx.doi.org/10.1016/j.apsusc.2012.05.156
12. Rozati S.M., Akesteh Sh. Characterization of $\mathrm{ZnO}$ :Al thin films obtained by spray pyrolysis technique. Mater. Charact., 2007, vol. 58, pp. 319-322. http://dx.doi.org/10.1016/j.matchar.2006.05.012

Inna Juhnevica, Dr. sc. ing. (2003 at Riga Technical University). Since 1998 has worked at Riga Technical University, Institute of Silicate Materials as a senior research scientist and an associate professor. She has authored 23 scientific publications and supervises bachelor, master and doctoral students. E-mail: innaju@ktf.rtu.lv

Marija Masonkina, Mg. sc. ing. (2013) is a doctoral student at Riga Technical University. Since 2013 she has worked at Riga Technical University, Institute of Silicate Materials as a researcher.

E-mail: marija.masonkina@rtu.lv

Gundars Mezinskis, Dr. habil. sc. ing. (1998 at Riga Technical University). Since 1998 he has worked at Riga Technical University, Institute of Silicate Materials as the head of the Institute and a professor

$\mathrm{He}$ has authored 158 scientific publications and supervises bachelor, master and doctoral students.

E-mail: gundarsm@ktf.rtu.lv

Alona Gabrene, Mg. sc. ing. (2012) is a doctoral student at Riga Technical University. Since 2007 she has held the position of research scientist and lecturer at Riga Technical University, Institute of Silicate Materials. She is a co-author of 7 scientific publications and supervises of bachelor students.

E-mail: alona.gabrene@ rtu.lv

Inna Juhṇeviča, Marija Mašonkina, Gundars Mežinskis, Aḷona Gabrene. ZnO un ZnO/Al pārklājumu iegūšana ar iemērkšanasizvilkšanas metodi un to īpašības.

Pēdējos gados $\mathrm{ZnO}$ plānie pārklājumi ieņēmuši nozīmīgu vietu jaunajās tehnoloǵijās. Tiem ir plašs pielietojumu diapazons - gan zinātnē, gan tehnologijāa. ZnO plānos pārklājumus var izmantot saules baterijās, gāzu sensoros, pjezoelektriskās ierīcēs, kā katalizatorus un vēl daudzās dažādās sfērās. Legeejot cinka oksīdu, ir iespējams izveidot materiālu ar izcilām elektriskajām īpašībām. Kā leǵējošos jonus var izmantot I, V un retzemju grupu elementus. No visiem uzskaitītajiem elementiem tieši leǵēešana ar $\mathrm{Al}^{3+}$ joniem var veicināt struktūru ar defektiem veidošanos, izmainīt optiskās un elektriskās īpašības. Iespējamas vairākas metodes $\mathrm{ZnO} / \mathrm{Al}$ pārklājumu iegūšanai, piemēram, ķīmiskā tvaika kondensēšana, pulsējošā lāzera nogulsnēšana, uzputināšana un sola-gēla metode. Salīdzinot sola-gēla metodi ar citām metodēm, tās priekšrocības ir nelielas izmaksas un viegli realizējams process.

$\mathrm{ZnO}$ un $\mathrm{ZnO} / \mathrm{Al}^{3+}$ plānos pārklājumus uz nātrija-silikātu stikla virsmas ieguva, izmantojot sola-gēla iemērkšanas-izvilkšanas metodi. Tika noteikta apdedzināšanas režīma ietekme uz plānā pārklājuma morfoloğiju. Paraugu virsma, kuru paḳ̣āva „šoka” apdedzināšanai, bija kvalitatīvākā, bez redzamiem defektiem, ar augstāko raupjuma pakāpi un pārklājumu veidojošās daḷiņas bija mazāka izmēra.

Pētījuma rezultāti liecina, $\mathrm{ka} \mathrm{Al}^{3+}$ jonu ievadīšana $\mathrm{ZnO}$ sola-gēla sastāvā izmaina plānā pārklājuma morfolog̣iju un īpašības. $\mathrm{Al}^{3+}$ jona koncentrācijas paaugstināšana $\mathrm{ZnO}$ sola-gēla sastāvā veicina $\mathrm{ZnO}$ dalinu izmēra samazināšanos pārklājumā un blīvāka pārklājuma veidošanos.

\section{Инна Юхневича, Мария Машонкина, Гундарс Межинскис, Алёна Габрене. Получение тонких покрытий ZnO и ZnO/Al методом золь-гель и их свойства.}

$\mathrm{B}$ последние годы именно тонкие покрытия $\mathrm{ZnO}$ занимают значительное место в новых технологиях и покрывают огромный диапазон применения в различных технологиях и науке. Тонкие покрытия ZnO можно использовать в солнечных батареях, сенсорах, пьезоэлектрических установках и других сферах. Легируя оксид цинка, можно получить материал с уникальными электрическими свойствами. Легирующими ионами могут быть элементы I, V группы и редкоземельные элементы. Ионы $\mathrm{Al}^{3+}$ могут быть использованы для создания структуры с элементами дефектов, а так же для улучшения оптических и электрических свойств.

Для получения $\mathrm{ZnO} / \mathrm{Al}$ покрытий могут быть использованы разные методы, например, химическая конденсация из газообразной фазы, осаждение, напыление, а также технология золь-гель. Сравнивая метод золь-гель с другими методами, метод золь-гель имеет преимущества в сравнительно низких затратах и в простате реализуемого процесса.

Тонкие покрытия $\mathrm{ZnO}$ и ZnO/Al были нанесены на натрий-силикатную стеклянную подложку методом окунания в растворы золь-гель. Было проверено влияние режима обжига на морфологию тонких покрытий. Поверхность образцов, которые подверглись шоковому режиму термообработки, была более качественная, без видимых дефектов, с вышей степенью шероховатости и частицы, образующие поверхность покрытия, были с меньше по размерам.

Результаты исследования указывают, что введение иона алюминия в состав золей ZnO изменяют морфологию и свойства тонких покрытий. Повышение концентрации иона алюминия в золь-гель $\mathrm{ZnO}$ составах ведёт к уменьшению размера частицы покрытия и образованию более плотной поверхности покрытия. 
